\title{
UNCERTAINTY REGULATION: THE MASTER MOTIVE ? 不確定性の調整：最上の動機?
}

\author{
講演者 Richard M. Sorrentino \\ The University of Western Ontario \\ 企画者 大坪靖直（福岡教育大学） 甲原定房（山口県立大学） 笹山郁生（福岡教育大学） \\ 企画者·司会安永 悟 (久留米大学) \\ 企画者·指定討論 山口 勧 (東京大学) \\ 通訳森尾 博昭（東京大学）
}

\section{講演者の紹介}

Sorrentino 教授は，Atkinson やRokeach，Kagan などの流れを汲む不確定志向性理論の提唱者である。不確定 志向性理論とは，不確定な状況に対する志向性の個人差を説明する理論であり，社会心理学において明らかにされた 理論の多くが，不確定志向性の高い個人にのみあてはまるということを，多くの研究から実証してこられた。本講演 では, 不確定志向性理論の概要と, 現在の氏の興味の焦点である不確定志向性と文化との関連についてお話しいただ く。

\section{講演の内容}

Although some people believe that uncertainty is something to be feared or avoided, it is argued here that most people develop a way of life in which uncertainty is regulated, such that it does not interfere with everyday activity. Our research program indicates that people gravitate towards two systems of uncertainty regulation. There are those that move towards the end of a continuum where uncertainty is considered something to be approached and resolved, with the goal of attaining clarity. We call these people uncertainty-oriented. Others move towards the other end of the continuum where certainty is considered something to be valued, with the goal of maintaining clarity. Our research program also suggests that most other motivational systems are in the service of one's mode of uncertainty regulation. This research has demonstrated that one's uncertainty orientation, either alone or in interaction with other motives, is important in all domains of everyday life events, from achievement activities to trust in close relationships, and from self-assessment to group dynamics. One of the most overarching findings is that people will only systematically process information when it is consistent with their uncertainty orientation. Otherwise, they will use more automatic forms of information processing. Our research has also been shown to have significant impact on health related activities such as undertaking health protection behavior, avoiding depression, and may be critical for psychotherapy. The next big step in the research program has been to move to the cross-culture domain. Just as individuals gravitate towards one end of this continuum or another, various cultures and subcultures are seen to also vary. Research investigating these differences in Japan, Canada and other countries is consistent with this assumption. Japanese students, for example, have been found in three studies to be significantly more certainty-oriented and less uncertainty-oriented than Canadian students. Interestingly, and consistent with our theory of uncertainty regulation, those students who do not match what may be the overall uncertainty orientation of their culture, tend to react more passively and negatively in their everyday lives and show evidence of defensive or unstable behavior. All of this leads to our preliminary conclusion that uncertainty regulation may well be the key variable when it comes to examining differences and similarities from one culture to another.

\section{主な著書・論文}

Sorrentino, R. M., \& Higgins, E. T. (Eds.) (Vol. 1, 1986; Vol. 2, 1990; Vol. 3, 1996). The Handbook of Motivation and Cognition. New York : The Guilford Press.

Sorrentino, R. M., Otsubo, Y., Yasunaga, S. Nezlek, J., Kouhara, S. \& Shuper, P. (2005). Uncertainty orientation and social behavior: Individual differences within and across cultures. In R. M. Sorrentino, D. Cohen, J. M. Olson, \& M. P. Zanna (Eds.) Culture and Social Behavior: The Ontario Symposium. Vol. 10. New York : Lawrence Earlbaum Associates. (181-205).

Sorrentino, R. M. and Roney, C. J. R. (2000) The Uncertain Mind: Individual Differences in Facing the Unknown. London : Psychology Press. (安 永悟・大坪靖直・甲原定房訳 2003 未知なるものに摇れる心 : 不確定志向性理論からみた個人差＼cjkstart北大路書房) 